\title{
Evaluasi terhadap Pembangunan PLB Terkait dengan Perspektif Sosial Masyarakat di Kecamatan Nanga Badau
}

\author{
Ade M Yuardani, Didi Zulyanto, \& Agus Eko Tejo \\ Program Studi Administrasi Negara, Jurusan Administrasi Bisnis, Politeknik Negeri Pontianak \\ Jalan Ahmad Yani Pontianak 78124 \\ E-mail: minsut_benuis@yahoo.com
}

\begin{abstract}
Abstrak
Permasalahan yang sering di hadapi dalam penanggulangan masyarakat miskin ini adalah luasnya wilayah serta sulitnya jangkauan ke daerah-daerah miskin yang ada di Kapuas Hulu serta masih rendahnya kualitas infrastruktur yang dimiliki. Perbatasan merupakan wilayah terdepan suatu bangsa, begitu juga dengan Kecamatan Nanga Badau, yang berbatasan dengan Serawak Malaysia, memiliki potensi alam yang masih dapat dikembangkan agar masyarakat yang ada di perbatasan. Penelitian ini bertujuan untuk mengungkap dampak pembangunan PLB kecamatan Nanga Badau Kabupaten Kapuas Hulu terhadap kesejahteraan masyarakat di Nanga Badau. Adapun yang menjadi informan dalam penelitian ini adalah Camat Badau, Kadis Ekonomi Bappeda Kapuas hulu, Sekretaris Diknas kapuas hulu, dan tokoh masyarakat di perbatasan. Setelah data terkumpul diolah dengan menggunakan metode deskriptif kualitatif. Hasil penelitian ini berdasarkan wawancara dan observasi bahwa PLB Badau masih belum mampu memberikan perubahan yang berarti terhadap perekonomian masyarakat, di sektor pendidikan sudah terdapat perubahan dimana yang dahulu perbatasan merupakan daerah tertinggal sekarang tidak terjadi lagi, pada aspek politik juga masyarakat sudah memiliki kemampuan yang cukup dalam keikutsertaannya terhadap pesta demokrasi di Kapuas Hulu, masyarakat di perbatasan tidak dijadikan obyek akan tetapi sebagai subyek politik itu sendiri.
\end{abstract}

Kata kunci: pembangunan, kebijakan, kesejahteraan

\section{PENDAHULUAN}

Propinsi Kalimantan Barat terletak di bagian barat pulau Kalimantan atau di antara garis $2^{\circ} 08^{\prime}$ LU serta $3^{\circ} 05^{\prime}$ LS serta di antara $108^{\circ} 0^{\prime}$ BT dan $114^{\circ} 10^{\prime}$ BT pada peta bumi. Berdasarkan letak geografis yang spesifik ini maka, daerah Kalimantan Barat tepat dilalui oleh garis Khatulistiwa (garis lintang $0^{\circ}$ ) tepatnya di atas Kota Pontianak. Karena pengaruh letak ini pula, maka Kalbar adalah salah satu daerah tropik dengan suhu udara cukup tinggi serta diiringi kelembaban yang tinggi.

Ciri-ciri spesifik lainnya adalah bahwa wilayah Kalimantan Barat termasuk salah satu propinsi di Indonesia yang berbatasan langsung dengan negara asing, yaitu dengan Negara Bagian Serawak, Malaysia Timur. Bahkan dengan posisi ini, maka daerah Kalimantan Barat kini merupakan satu-satunya propinsi di Indonesia yang secara resmi telah mempunyai akses jalan darat untuk masuk dan keluar dari negara asing. Hal ini dapat terjadi karena antara Kalbar dan Sarawak telah terbuka jalan darat antar negara Pontianak Entikong - Kuching (Sarawak, Malaysia) sepanjang sekitar $400 \mathrm{~km}$ dan dapat ditempuh sekitar enam sampai delapan jam 
perjalanan. Batas-batas wilayah selengkapnya bagi daerah propinsi Kalbar adalah:

- Utara : Sarawak (Malaysia)

- Selatan : Laut Jawa \& Kalteng

- Timur : Kalimantan Timur

- Barat : Laut Natuna dan Selat Karimata

Sebelah utara Kalbar terdapat empat kabupaten yang langsung berhadapan dengan negara jiran yaitu; Sambas, Sanggau, Sintang dan Kapuas Hulu. Sebagai darah yang berbatasan langsung dengan negara tetangga memiliki keuntungan dan tantangan tersendiri yang dihadapi kalimantan barat. Kecamatan badau merupakan wilayah Kabupaten Kapuas Hulu yang berbatasan dengan serawak malaysia telah dibangun Pos lintas Batas (PLB) untuk memberikan legalitas keluarnya orang dan barang melewati Kapuas Hulu.

Pembangunan masyarakat dewasa ini yang dilaksanakan pemerintah tentunya memerlukan pendanaan yang cukup besar, sehingga program pemberdayaan yang sudah di rencanakan berjalan dengan lancar dan mendapatkan hasil maksimal. Pembedayaan masyarakat miskin di kalimantan barat dewasa ini sedang digalakkan. Pemberdayaan masyarakat yang bertujuan untuk meningkatkan kesejahteraan masyarakat miskin di arahkan di berbagai bidang.

Badan perencanaan pembangunan Daerah Kabupaten yang merupakan Badan yang bertanggung jawab terhadap perencanaan pembangunan berkewajiban untuk membuat berbagai program dan menginventarisir berbagai proyek pembangunan di Daerah ini. Program pembangunan yang di rencanakan dan di laksanakan bukan hanya terkait dengan infrastruktur saja akan tetapi juga terkait dengan pembangunan ekonomi masyarakat.
Program pemberdayaan yang direncanakan BAPPEDA terkait dengan pemberantasan kemiskinan, memerlukan strategi dan komitmen yang kuat. Luasnya wilayah Kalimantan barat dan masih rendahnya tingkat pendidikan penduduk miskin di Kalimantan Barat membuat program yang di rencanakan sulit mendapatkan hasil yang maksimal. Pemberantasan kemiskinan yang di lakukan ini bukan hanya terkait dengan kebijakan daerah akan tetapi program ini di atur dalam Undangundang di mana pemberantasan kemiskinan ini merupakan program pemerintah pusat, sehingga daerah perlu membentuk tim penanggulanan kemiskinan di daerah masingmasing.

Permasalahan yang sering di hadapi dalam penanggulangan masyarakat miskin ini adalah luasnya wilayah serta sulitnya jangkauan ke daerah-daerah miskin yang ada di Kapuas Hulu serta masih rendahnya kualitas infrastruktur yang dimiliki. Permasalahan lainnya juga sering terjadi adalah masih rendahnya partisipasi masyarakat dalam keterlibatan mereka terhadap program yang di rencanakan pemerintah. Sulitnya mendapatkan partisipasi masyarakat dewasa ini hanya di karenakan sudah sekian lama masyarakat di wilayah perbatasan diabaikan oleh pemerintah sehingga ini yang menyebabkan masyarakat hampir tidak terlalu memperdulikan program pemerintah.

Dalam perjalannya sejak dibangun PLB ini peneliti masih beranggapan bahwa PLB ini belum memberikan perubahan yang positif terhadap kehidupan masyarakat yang berada di kapuas Hulu pada umumnya dan khususnya masyarakat kecamatan Badau dalam beberapa hal seperti peningkatan kesejahteraan masyarakat, lebih khususnya lagi dapat dikatakan bahwa masih belum tercapainya 
pembangunan sosial yang diterjadi di kecamatan Badau sebagai daerah perbatasan.

\section{Ruang Lingkup Penelitian}

Perbatasan merupakan wilayah terdepan suatu bangsa, begitu juga dengan Kecamatan Nanga Badau. Kecamatan Nanga Badau yang berbatasan dengan Serawak Malaysia memiliki potensi alam yang masih dapat dikembangkan agar masyarakat yang ada di perbatasan. Masyarakat perbatasan merupakan bagian dari warga negara Republik Indonesia sudah seharusnya mendapatkan kesempatan seperti masyarakat lainnya terutama dalam hal kesejahteraan. Agar penelitian ini lebih terarah dan terfokus maka peneliti membatasi penelitian ini pada evaluai terhadap pembangunan PLB terkait dengan perspektif sosial masyrakat yang ada di kecamatan Nanga Badau.

\section{Perumusan Masalah}

Berdasarkan latar belakang dan ruang lingkup penelitian diatas maka dapat penulis rumuskan penelitian ini sebagai berikut: bagaimanakah dampak pembangunan PLB kecamatan Nanga Badau Kabupaten kapuas hulu terhadap kesejahteraan masyarakat di Nanga Badau?

\section{Tujuan Penelitian}

Adapun penelitian ini bertujuan untuk :

(1) Ingin mengetahui tanggapan masyarakat terhadap PLB serta dampak positif terhadap kehidupan masyarakat

(2) Ingin mengetahui faktor - faktor pemdukung pembangunan kawasan perbatasan kecamatan badau.

\section{KAJIAN PUSTAKA}

Berhasil tidaknya suatu pembangunan akan dilaksanakan tergantung dari perencanaan yang akan di buat oleh seorang maupun badan perencanana. Kebijakan dalam perencanaan yang di arahkan pada sektorsektor tertentu juga harus di imbangi dengan komitmen, serta di tuangkan dalam kebijakan pemerintah. Usaha pemerintah dalam menanggulangi kemiskinan tertuang dalam tiga arah kebijaksanaan, yaitu: kebijaksanaan tidak langsung, kebijaksanaan langsung dan kebijaksanaan khusus. Kartasasmita, (1996:241-242).

Pelaksanaan pembangunan tidak hanya dilakukan oleh pemerintah saja akan tetapi juga memerlukan keterlibatan masyarakat banyak. Pembangunan yang melibat banyak pihak atau dengan kata lain menggunakan partisipasi masyarakat akan memberikan hasil yang lebih baik dibandingkan dengan pembangunan yang direncanakan oleh seorang perencana sendiri. partisifatip merupakan paradigma yang relevan dalam memgembangkan sumber daya manusia dalam pembangunan suatu daerah. Bagaimana pembangunan partisipatif di lakukan, seperti dikatakan Adisasmita (2006:38) pembangunan partisipatif di lakukan menyangkut bebarapa cara "1) Tahap-tahapan kegiatan yang di lakukan; 2) Analisis yang harus di sampaikan; 3) Penyusunan program yang di butuhkan masyarakat setempat; dan 4) Implementasi program pembangunan yang di tetapkan". Pembangunan yang mengedepankan partisipasi masyarakat dewasa ini lebih kepada pemberdayaan masyarakat. Konsep pemberdayaan inilah yang seharusnya di kembangkan pemerintah dalam melaksanakan berbagai program pembangunan.

Dalam berbagai program yang dilaksanakan diperlukan berbagai kebijakan yang dijadikan pedoman dalam pelaksanaannya nantinya. kebijaksanaan negara adalah segala sesuatu hal yang dinyatakan dan tindakan yang dilakukan atau tidak dilakukan 
oleh pemerintah, mempunyai sifat memaksa melalui pengalokasian nilai-nilai yang dapat diwujudkan berupa pernyataan, pidato, peraturan, program dan kegiatan untuk mengatasi masalah, mempunyai tujuan tertentu dan untuk kepentingan masyarakat. Sesuatu yang tidak dilakukan oleh pemerintah termasuk kebijaksanaan negara karena hal tersebut akan dapat memberikan pengaruh/ dampak yang sama besarnya dengan sesuatu yang dilakukan pemerintah.

Anderson dalam Irfan (2000: 17) mengatakan kebijaksanaan adalah: "Serangkaian tindakan yang mempunyai tujuan tertentu yang diikuti dan dilaksanakan oleh seorang pelaku atau sekelompok pelaku guna memecahkan suatu masalah tertentu". Raksasataya dalam Irfan (2000: 17) mengemukakan "Kebijaksanaan sebagai suatu taktik dan strategi yang diarahkan untuk mencapai suatu tujuan. Dengan demikian kebijaksanaan dapat diartikan sebagai suatu tindakan yang ditetapkan dan dilaksanakan oleh seorang pelaku atau sekelompok pelaku yang dapat berupa program, keputusan, ketentuanketentuan, peraturan perundang-undangan yang mempunyai tujuan dan untuk memecahkan masalah melalui pengarahan strategi.

Kebijakan publik secara sederhana adalah konsep dasar rencana pemerintah atau organisasi publik untuk mengatur kepentingan umum atau orang banyak. Sedangkan Secara umum, Pengertian Kebijakan Publik adalah segala sesuatu yang dikerjakan dan tidak dikerjakan oleh pemerintah untuk kepentingan umum. Segala sesuatu yang dimaksud adalah setiap aturan dalam kehidupan bersama, baik itu hubungan antarwarga maupun warga dengan pemerintah.
Kebijakan publik biasanya dituangkan dalam peraturan perundang-undangan seperti undang-undang (UU), peraturan presiden, dan peraturan daerah (perda) merupakan bentukbentuk kebijakan publik. Kebijakan publik atau kebijakan umum merupakan programprogram yang diterapkan oleh pemerintah dalam arti luas untuk mencapai tujuan masyarakat. Dengan kata lain, kebijakan publik adalah suatu keputusan - keputusan dari lembaga yang berwenang atau pemerintah yang menyangkut kepentingan masyarakat luas.

Menurut Suharto (2013:33), “Kebijakan publik adalah keputusan-keputusan atau pilihan-pilihan tindakan yang bersifat strategis atau garis besar yang secara langsung mengatur pengelolaan dan pendistribusian sumber daya publik (alam, finansial, dan manusia) demi kepentingan rakyat banyak, penduduk, masyarakat, atau warga Negara. Selain itu, kebijakan publik menurut Eystone dalam Wahab (2016:13), "Kebijakan publik adalah antar hubungan yang berlangsung di antara unit/satuan pemerintahan dengan lingkungannya". Seperti yang telah dikatakan Gerston dalam Wahab (2016:16), "menegaskan bahwa semua kebijakan publik melibatkan pemerintah dalam beberapa cara".

Sedangkan menurut Thomas R Dye dalam Wahab (2016:13), “Kebijakan publik ialah pilihan tindakan apapun yang dilakukan atau tidak ingin dilakukan oleh pemerintah". Selanjutnya, menurut Udoji dalam Wahab (2016:126), "Pelaksanaan kebijakan adalah sesuatu hal penting bahkan mungkin jauh lebih penting daripada pembuatan kebijakan. Kebijakan akan berupa impian atau rencana bagus yang tersimpan rapi dalam arsip kalau tidak diimplementasikan." Oleh karena itu, setiap kebijakan haruslah diimplementasikan 
untuk mencapai tujuan yang telah ditetapkan dari kebijakan tersebut walaupun hasiltidak sesuai dengan yang diharapkan. Seperti yang dikatakan Wilson dalam Wahab (2016:13), "Kebijakan publik ialah tindakan-tindakan, tujuan-tujuan, dan pernyataan-pernyataan pemerintah mengenai masalah-masalah tertentu, langkah-langkah yang telah/sedang diambil (atau gagal diambil) untuk diimplementasikan, dan penjelasan-penjelasan yang diberikan oleh mereka mengenai apa yang terjadi (atau tidak terjadi)."

Menurut Nugroho (2003:158) Implementasi kebijakan pada prinsipnya adalah cara sebuah kebijakan dapat mencapai tujuannya tidak kurang tidak lebih. Untuk mengimplementasikan kebijakan publik, maka ada dua pilihan langkah yang ada, yaitu langsung mengimplementasikan dalam bentuk program - program atau melalui formulasi kebijakan derivate atau turunan dari kebijakan publik tersebut.

Pada prinsipnya terdapat dua jenis teknik atau model implementasi kebijakan yang berpola "dari atas kebawah" (top - bottomer) versus dari "bawah ke atas" (bottom - topper), dan pemilahan implementas yang berpola paksa (command - and - control) dan mekanisme pasar (economic incentive). Selain merumuskan dan mengimplementasikan kebijakan juga diperlukan monitoring supaya kebijakan yang dilaksanakan sesuai dengan tujuan yang telah ditetapkan. Dari definisi diatas penulis menyimpulkan bahwa implementasi kebijakan merupakan kegiatan yang dilakukan oleh pemerintah dengan melibatkan berbagai pihak - pihak secara efektif untuk mencapai tujuan dari kebijakan itu sendiri. Selain merumuskan dan mengimplementasikan juga diperlukan monitoring yang bertujaun supaya kebijakan yang dilaksanakan sesuai dengan tujuan yang ingin dicapai.

Monitoring adalah penilaian secara terus menerus terhadap fungsi kegiatan - kegiatan program - program didalam hal jadwal penggunaan input / masukan data oleh kelompok sasaran berkitan dengan harapan harapan yang telah direncanakan. Menurut Peraturan Pemerintah Nomor 39 Tahun 2006, disebutkan bahwa monitoring merupakan suatu kegiatan mengamati secara saksama suatu keadaan atau kondisi, termasuk juga prilaku atau kegiatan tertentu, dengan tujuan agar semua data masukan atau informas yang diperoleh dari hasil pengamatan tersebut dapat menjadi landasan dalam mengambil keputusan tindakan selanjutnya yang diperlukan. Tindakan tersebut diperlukan seandainya hasil pengamatan menunjukan adanya hal atau kondisi yang tidak sesuai dengan yang direncanakan semula.

Agar kegiatan dan program dapat berjalan dengan baik dan sebagai bahan pembuatan kebijakan berikutnya, maka kegiatan ataupun program tersebut perlu dilakukan evaluasi terkait dengan hasil yang terjadi pada tahun sebelumnya. Menurut Nugroho (2003: 184) evaluasi kebijakan publik acapkali hanya dipahami sebagai evaluasi atas implementasi kebijakan saja. Sesungguhnya evaluasi kebijakan publik mempunyai tiga lingkup makna, yaitu evaluasi perumusan kebijakan, evaluas implementasi kebijakan, dan evaluas lingkungan kebijakan. Oleh karena ketiga komponen tersebutlah yang menentukan apakah kebijakan akan berhasil guna atau tidak. Namun demikian, konsep didalam konsep"evaluasi" sendiri selalu terikut konsep "kinerja", sehingga evaluas kebijakan publik pada ketiga wilayah bermakna "kegiatan pasca". Pembedaan ini 
penting untuk memilahkannya dengan "analisa" (kebijakan). Oleh karena itu, evaluasi kebijakan publik tidak hanya dengan implementasinya, melainkan berkenaan dengan perumusan, implementasi, dan lingkungan kebijakan publik.

Dunn (2000 : 608) menjelaskan bahwa, "secara umum evaluasi dapat disamakan dengan penaksiran (appraisal), pemberian angka (rating), penilaian (assessment), dan usaha untuk menganalisis hasil kebijakan. Dalam arti spesifik, evaluasi berkenaan dengan produksi informas mengenai nilai atau manfaat hasil kebijakan”. Sementara itu Dunn (2000: 28) juga mengatakan, "evaluasi menghasilkan ketidak sesuaian antara kinerja kebijakan yang diharapkan dengan yang dihasilkan. Evaluasi menghasilkan kesimpulan mengenai seberapa jauh masalah telah terselesaikan, juga menyumbang pada klasifikasi dan kritik terhadap nilai - nilai yang mendasari kebijakan, membantu dalam penyesuaian dan perumusan kembali masalah". Dengan demikian bahwa dari kegiatan evaluasi paling tidak dapat diketahui capaian kinerja kebijakan.

Berdasarkan berbagai pendapat di atas, dapat dikatakan bahwa sesungguhnya evaluasi adalah merupakan bagian akhir dari proses manajemen dalam rangka untuk mengukur atau mengetahui tingkat capaian dari suatu kebijakan atau program. Dari kegiatan evaluasi akan diketahui atau tergambar tingkat kinerja suatu organisasi. Oleh Karena itu kegiatan evaluasi tidak boleh dipandang sebelah mata, tetapi hendaknya dipandang sebagai suatu kegiatan yang strategis dalam upaya pencapaian tujuan kebijakan / program.

Selain merumuskan, mengimplementasikan dan mengevaluasi, juga diperlukan kebijaksanaan dari pembuat kebijakan itu sendiri. Kebijaksanaan dapat dipahami bahwa segala sesuatu hal yang dinyatakan dan tindakan yang dilakukan atau tidak dilakkan oleh pemerintah, mempunyai sifat memaksa melalui pengalokasian nilai - nilai yang dapat diwujudkan berupa pernyataan, pidato, peraturan, program dan kegiatan untuk mengatasi masalah, mempunyai tujuan tertentu dan untuk kepentingan masyarakat. sesuatu yang tidak dilakukan oleh pemerintah termasuk kebijaksanaan negara karena hal tersebut akan dapat meberikan pengaruh / dampak yang sama besarnya dengan sesuatu yang dilakukan pemerintah. Anderson dalam Irfan (2000 : 17), mengatakan kebijaksanaan adalah serangkaian tindakan yang mempunyai tujuan tertentu yang diikuti dan dilaksanakan oleh seorang pelaku atau sekelompok pelaku guna memecahkan suatu masalah tertentu.

Penyelenggaraan pemerintahan yang baik memerlukan orang - orang yang memiliki kemampuan serta memahamai dan menaati berbagai peraturan (kebijaksanaan) yang sudah dibuat. Kebijaksanaan menurut Islamy (2000 : 20) mempunyai implikas sebagai berikut :

a. Kebijaksanaan negara itu dalam bentuk perdanannya berupa penetapan tindakan tindakan pemerintah.

b. Tidak cukup hanya dinyatakan tetapi dilaksanakan dalam bentuknya yang nyata.

c. Untuk melakukan sesuatu atau tidak melakukan sesuatu itu mempunyai dan dilandasi dengan maksud dan tujuan tertentu.

d. Harus senantiasa ditujukan bagi kepentingan seluruh anggota masyarakat.

Selanjutnya ciri - ciri kebijakan pemerintah, sebagaimana yang dikemukankan oleh Suradinata (1993 : 192) sebagai berikut: 
a. Adanya hubungan dengan tujuan organisasi;

b. Dikomunikasikan kepada semua pihak;

c. Menggunakan bahasa tertulis dan sederhana;

d. Adanya batas dan ukuran bagi tindakan di kemudian hari;

e. Memungkinkan perubahan meskipun relatif tetap dan stabil;

f. Mudah dilaksanakan oleh mereka yang bertanggung jawab dalam pelaksanaannya.

\section{METODE PENELITIAN}

Jenis penelitian ini bersifat deskriptif kualitatif, dimana hasil dari penelitian ini dapat memberikan gambaran bagaimana kondisi masyarakat yang ada dikapuas hulu terutama di perbatasan. Selama penelitian dilakukan penulis mengembangkan konsep dan menghimpun data, fakta akan tetapi penulis tidak akan melakukan pengujian hipotesa (Singgarimbun, 1989 : 4).

Adapun lokasi penelitian dilakukan di Kabupaten Kapuas Hulu adapun yang dijadikan obyek penelitian ini adalah masyarakat di perbatasan dengan pertimbangan sebagai berikut:

a. Diidentifikasikan masyarakat di perbatasan masih tertinggal dibandingkan, dengan daerah pesisir di kapuas hulu.

b. Kurangnya keseriusan pemerintah pusat dalam menangani permasalahan di perbatasan.

Adapun yang menjadi informan dalam penelitian ini adalah Masyarakat Badau, Sekretaris Bappeda, Anggota DPRD Kapuas Hulu dan Camat Badau serta tokoh masyarakat Adapun pertimbangan penentuan subyek penelitian dan informan kunci dengan alasan bahwa mereka adalah orang-orang yang mengalami mengenai apa yang penulis inginkan.

Untuk menghasilkan data yang dibutuhkan peneliti melakukan beberapa hal sebagai berikut:

1. Observasi, penulis turun langsung untuk memperoleh data dan informasi, sesuai dengan tujuan penelitian secara partisipasi. Arikunto (1993:223) menyatakan metode observasi adalah suatu usaha sadar untuk mengumpulkan data yang dilakukan secara sistematis, dengan prosedur yang standar.

2. Wawancara, dilakukan secara langsung kepada informan yang terdiri Masyarakat Badau,Sekretaris Bappeda, Anggota DPRD Kapuas Hulu dan Camat Badau serta tokoh masyarakat yang memahami apa yang menjadi fokus penelitian. Moleong (1994 : 135) mengatakan bahwa wawancara adalah percakapan dengan maksud tertentu yang dilakukan oleh dua pihak yaitu pewawancara dengan pihak yang diwawancarai.

3. Dokumentasi yaitu penulis melakukan pengumpulan data dan informasi melalui catatan-catatan resmi, surat-surat dan dokumentasi lainnya yang dapat mendukung penelitian yang penulis lakukan.

Setelah data dan informasi terkumpul, selanjutnya penulis mengkategorikan dan mencocokkan dengan teori, selanjutnya di analisis secara kualitatif dalam bentuk deskriptif analisis. Amirin (1990 : 95) menyatakan analisis kualitatif pada dasarnya mempergunakan pemikiran logis, analisa dan logika, induksi, deduksi analogi, komparasi dan sejenisnya. Sehubungan dengan itu Moleong (1994 : 3) menyatakan penelitian kualitatif sebagai prosedur penelitian yang 
menghasilkan data deskriptif berupa kata-kata tertulis atau dari orang-orang dan perilaku yang diamati. Setelah semua data terkumpul maka penulis menguraikan tulisan ini dengan menggunakan kata tanpa mempergunakan angka-angka.

\section{HASIL}

Secara Administratif dalam wilayah Kecamatan ini terdapat 6 (enam) Desa, yaitu Desa Badau, Desa Janting, Desa Kekurak, Desa Semuntik, Desa Majang, Dan Desa Sering. Luas total Wilayah Kecamatan ini mencapai 70.000 hektar. Ibukota Kecamatan Badau terletak di desa Badau berada pada posisi yang sangat strategis untuk berkembang karena memiliki luas kedua dari 6 Desa yang ada dan memiliki potensi untuk bergeraknya arus orang dan barang ke Badau. Jarak tempuh ke Kecamatan Badau, dari Kabupaten Kapuas Hulu ke Badau 177 KM sekitar 4-5 jam apabila jalannya dalam kondisi baik, sedangkan jarak tempuh dari pemerintah Provinsi Kalimantan Barat ke Badau 818 KM dapat ditempuh dengan jalan darat apabila dalam kondisi baik selama 26 jam.

Kabupaten Kapuas Hulu merupakan salah satu kabupaten di Provinsi Kalimantan Barat yang wilayahnya berbatasan langsung dengan wilayah negara bagian Sarawak Malaysia Timur. Terdapat 7 (tujuh) Kecamatan Lini I di Kabupaten Kapuas Hulu, yaitu: Puring Kencana, Empanang, Badau, Batang Lupar, Embaloh Hulu, Putussibau utara, dan Putussibau Selatan. Kabupaten ini memiliki luas wilayah $16.857 \mathrm{Km}^{2}$. Di Kecamatan Badau, sejak tahun 2004 telah dibangun Pos Lintas Batas Negara (PLBN) Nanga Badau, namun sampai sekarang masih belum diresmikan sebagai Pos Pemeriksaan Lintas Batas (PPLB), sebagaimana layaknya
PPLB Entikong Kabupaten Sanggau. Hal ini tentunya menjadi tantangan tersendiri bagi Pemerintah Daerah Kabupaten Kapuas Hulu, untuk memperjuangkannya ke depan sebagai PPLB yang dapat berkontribusi terhadap perkembangan daerah dan bangsa, setelah dibentuknya Undang-Undang Nomor 43 Tahun 2008 Tentang Wilayah Negara dan Peraturan Pemerintah Nomor 12 tahun 2010 tentang Badan Nasional Pengelola Perbatasan (BNPP).

Berdasarkan Undang-Undang Nomor 43 Tahun 2008 tentang Wilayah Negara telah diatribusikan kewenangan Pemerintah, Pemerintah Provinsi, Pemerintah Kabupaten/Kota, sebagai berikut:

\section{a. Kewenangan Pemerintah}

Kewenangan Pemerintah dalam mengatur pengelolaan dan pemanfaatan wilayah negara dan kawasan perbatasan, adalah terfokus dalam:

1) menetapkan kebijakan pengelolaan dan pemanfaatan wilayah negara dan kawasan perbatasan;

2) mengadakan perundingan dengan negara lain mengenai penetapan batas wilayah negara sesuai dengan ketentuan peraturan perundang-undangan dan hukum internasional;

3) membangun atau membuat tanda batas wilayah negara;

4) melakukan pendataan dan pemberian nama pulau dan kepulauan serta unsur geografis lainnya;

5) memberikan izin kepada penerbangan internasional untuk melintasi wilayah udara teritorial pada jalur yang telah ditentukan dalam peraturan perundangndangan;

6) memberikan izin lintas damai kepada kapal-kapal asing untuk melintasi laut 
teritorial dan perairan kepulauan pada jalur yang telah ditentukan dalam peraturan perundang-undangan;

7) melaksanakan pengawasan di zona tambahan yang diperlukan untuk mencegah pelanggaran dan menghukum pelanggar peraturan perundang-undangan di bidang bea cukai, fiskal, imigrasi, atau saniter di dalam wilayah negara atau laut teritorial;

8) menetapkan wilayah udara yang dilarang dilintasi oleh penerbangan internasional untuk pertahanan dan keamanan; membuat dan memperbarui peta wilayah negara dan menyampaikannya kepada Dewan Perwakilan Rakyat sekurangkurangnya setiap 5 (lima) tahun sekali; dan

9) menjaga keutuhan, kedaulatan, dan keamanan Wilayah Negara serta kawasan perbatasan.

Selain kewenangan tersebut di atas, Pemerintah juga berkewajiban menetapkan biaya pembangunan kawasan perbatasan dan dapat menugasi pemerintah daerah untuk menjalankan kewenangannya dalam rangka tugas pembantuan sesuai dengan peraturan perundang-undangan.

\section{b. Kewenangan Pemerintah Provinsi}

Kewenangan Pemerintah Provinsi dalam pengelolaan wilayah negara dan kawasan perbatasan menurut Pasal 11 UU No. 43 Tahun 2008 adalah:

1) melaksanakan kebijakan Pemerintah dan menetapkan kebijakan lainnya dalam rangka otonomi daerah dan tugas pembantuan;

2) melakukan koordinasi pembangunan di kawasan perbatasan;

3) melakukan pembangunan kawasan perbatasan antar-pemerintah daerah dan/atau antara pemerintah daerah dengan pihak ketiga; dan

4) melakukan pengawasan pelaksanaan pembangunan kawasan perbatasan yang dilaksanakan Pemerintah Kabupaten/ Kota.

Dalam rangka melaksanakan kewenangan tersebut Pemerintah Provinsi juga berkewajiban menetapkan biaya pembangunan kawasan perbatasan.

\section{c. Kewenangan Pemerintah Kabupaten/ Kota}

Dalam pengelolaan wilayah negara dan kawasan perbatasan, Pemerintah Kabupaten/ Kota, berwenang:

1) melaksanakan kebijakan Pemerintah dan menetapkan kebijakan lainnya dalam rangka otonomi daerah dan tugas pembantuan;

2) menjaga dan memelihara tanda batas;

3) melakukan koordinasi dalam rangka pelaksanaan tugas pembangunan di kawasan perbatasan di wilayahnya; dan

4) melakukan pembangunan kawasan perbatasan antar pemerintah daerah dan/atau antara pemerintah daerah dengan pihak ketiga.

Dalam rangka melaksanakan kewenangan tersebut di atas, Pemerintah Kabupaten/Kota juga berkewajiban menetapkan biaya pembangunan kawasan perbatasan. Pemerintah Kabupaten kapuas Hulu memandang bahwa pembangunan akan berhasil dengan bak apabila aspek pendidikan memiliki prioritas untuk dikembangkan. Pendidikan merupakan sektor yang sangat penting untuk dikembangkan, Keberhasilan pemerintah dalam meningkatkan kemauan dan keasadaran masyarakat untuk sekolah sangat diapresiasikan. Kemajuan suatu daerah 
maupun bangsa akan terlihat dari tingkat pendidikan masayaratnya. Apabila semakin banyak masayarat yang tidak sekolah bahkan buta huruf akan sangat sulit bagi daerah tersebut Maupun Negara untuk berkembang seperti apa yang diharapkan.

Berdasarkan wawancara yang dilakukan dengan tokoh masyarakat perbatasan berkaitan dengan pembangunan PLB. Masyarakat menyambut positif terbukanya PLB di kecamatan Badau. Dengan terbukanya PLB memberikan kesempatan yang lebih baik pada masyarakatuntk mengembangkan semua potensi yang dimiliki masyarakat. Masyarakat diperbatasan yang terdiri dari tiga kecamatan yang terdekat dengan PLB merasakan manfaat yang besar. Menurut Informan dengan terbukanya PLB ini telah membuat mobilisasi orang dan barang ke badau atau keluar Badau menjadi lebih tinggi.

Berdasarkan wawancara dengan sekretaris Dinas Pendidikan Kabupaten Kapuas Hulu bahwa pengembangan pendidikan dewasa ini tidak terlalu mengalami permasalahan yang serius. Hal ini pertama dilihat dari animo masyarakat yang berkeinginan menjadi guru. Semakin banyak peminat yang mengingnkan menjadi guru merupakan peluang bagi pemerintah untuk mengembangkan dan memberikankan berbagai cara untuk meningkatkan mutu pendidikan.

Selain itu juga menurut Sekretaris Dinas Pendidikan Kapuas Hulu sikap masyarakat yang sudah sangat membuka diri untuk maju terutama mendapakan pendidikan. Keinginan masyarakat untuk menempuh pendidikan ini dikarenakan jarak antara sekolah dan pemukiman tidak terlalu jauh. Ini merupakan kondisi yang sangat memungkinkan bagi masyarakat untuk mendapatkan ilmu pengetahuan. Pemerintah Kabupaten Kapuas Hulu juga menyadari bahwa pendidikan sangat penting bagi pemerintah maupun masyarakat.

Berdasarkan wawancara yang dilakukan dengan masyarakat di Kecamatan badau, bahwa dengan semakin banyaknya guru dan perbaikan yang dilakukan oleh pemerintah kabupaten sektor pendidikan di perbatasan semakin baik, dan semakin berkurang masyarakat diperbatasan yang sekolah diluar negeri. Sebelumnya meneurut informan banyak masyarakat yang sekolah di beberapa wilayah di malaysia, seperti di Lubuk Antu, Miri, dan daerah lain di bagian Malaysia. Hal ini dilakukan maayarakat karena mereka diberikan fasilitas gratis dalam menempuh pendidikan, dan sarana prasarana yang diberikan jauh lebih baik. Akan tetapi sekarang kondisinya sudah membaik sehingga masyarakat terutama anak sekolah banyak memilih pendidikn di negara sendiri.

Berkembangnya sektor pendidikan akan sangat berpengaruh terhadap peningkatan ekonomi masyarakat. Apabila masyarakat memiliki penddikan yang memadai dan memiliki keterampilan yang baik, harapannya adalah sumberdaya yang ada di perbatasan dapat diekspolrasi oleh masyarakat setempat. Potensi alam yang dimiliki masyarakat perbatasan seperti perkebunan telah memberikan kontribusi pendapatan bagi maayarakat. Perkebunan dewasa ini sudah merupakan penyangga ekonomi yang kuat bagi masyarakat dalam memenuhi kebutuhan hidup keluarganya.

Sedangkan sektor pertanian juga sudah dilakukan sejak turun temurun, akan tetapi hasilnya masih belum maksimal. Masyarakat perbatasan yang memiiki akses sangat dekat dengan negara tetangga sudah sepantasnya dapat perhatian yang lebih dari pemerintah. Pembangunan di berbagai aspek perlu 
dilakukan agar terjadi keseimbangan pembangunan yang dilakukan oleh pemerintah diperbatasan maupun di daerah lain.

Pembangunan perbatasan yang dilakukan dewasa ini dilihat dari jumlah anggaran dan program sangat banyak dilakukan oleh pemerintah, baik yang dilakukan oleh pemerintah Pusat maupun pemerintah Daerah. Pemerintah Daerah dalam hal ini eksekutif dan legislatif juga memandang perlunya peningkatan pembangunan soaial politik di perbatasan. Hal ini dilakukan agar masayarat perbatasan memiliki kesempatan yang samadengan daerah lain dalam menikmati pembangunan. Selain itu juga pembangunan yang dilakukan di perbatasan akan dapat memberikan gambaran pada negara lain bahwa perbatasan bukanlah daerah terbelakang.

Semua Dinas dan Badan di lingkungan pemerintah Kabupaten Kapuas Hulu memandang penting pembangunan di perbatasan. Seperti dikatakan oleh Kepala Bidang ekonomi Bappeda Kabupaten Kapuas Hulu bahwa perbatasan merupakan daerah yang sudah ditetapkan sebagai daerah kawasan strategis Nasional. Sebagai daeah strategis Nasional banyak program yang sedang dan akan dilakukan di Kecamatan Badau, terutama pembangunan Infrastruktur. Selain itu juga pemerintah setelah melakukan penetapan Kecamatan badau sebagai Kawasan strategis nasional telah berupaya mengembangkan berbagai produk unggulan yang dihasilkan oleh masyarakat di Kecamatan Badau dan sekitarnya. Berdasarkan hasil wawancara dengan kabid, ekonomi Bappeda Kapuas hulu pengembangan perkebunan seperti Lada merupakan sektor yng juga dikembangkankan. Menurut Informan rantai pasok komunitas lada di kecamatan Badau dimulai dari penyedia bahan baku yaitu petani dan pemasaran yang dilakukan oleh pedagang pengumpul kecamatan dan pedagang perbatasan.

Pembangunan masyarakat di Perbatasan bukan hanya dari sektor pendidikan saja, akan tetapi dari sektor ekonomi juga merupakan perioritas yang dilakukan oleh pemerintah pusat dan daerah. Dilihat dari serapan tenaga kerja. Menurut tokoh masyarakat perbatasan sejak 10 tahun terakhir ini ini serapan tenaga kerja cukup tinggi, dimana pola pekerjaan masyarakat sudah bervariasi tidak hanya bercocok tanam seja, akan tetapi di sektor perkebunan seperti di pabrik pengolahan kelapa sawit sudah berkntribusi terhadap peningkatan pendapatan keluarga.

Hal ini juga disampaikan oleh sekretaris Camat Badau, bahwa dengan adanya PLB ini memberikan ruang kerja bagi masyarakat terhadap berbagai akses, guna meningkatkan kesejahteraan dan memenuhi kebutuhan pokok mereka. Pembangunan di perbatasan merupakan kewajiban dan keharusan yang dilakukan oleh pemerintah baik pemerintah Pusat maupun Pemerintah Daerah. Aparatur pemerintah diperbatasan juga telah berupaya untuk memajukan pembangunan diperbatasan.

Seperti dikatakan sekretaris Camat Badau, program pembangunan yang dilaksanakan di Badau merupakan prioritas pemerintah kabupaten dan Pemerintah Pusat. Sehingga dewasa ini banyak para akademisi dan mahasiswa pasca sarjana yang datang ke Badau ntuk melakukan penelitian dan pengembangan program yang mereka buat. Pemerintah dan masyarakat selalu bersinergi dalam membuat program yang akan diajukan kepemerintah Kabupaten untk dijadikan dasar membuat program pembangunan terutama di Kawasan Perbatasan. 
Berdasarkan hasil wawancara dengan tokoh masyarakat perbatasan, bahwa pembangunan PLB sudah memberikan dampak Positif terhadap peningkaan pendaatan masyarakat perbatasan, selain itu juga dilanjutkan Informan dari sisi pendidikan juga sudah meningkat dimana sekolah setingkat SMA sudah ada di perbatasan. Pembangunan masyarakat bukan hanya sebatas ekonomi dan pendidikan semata, akan tetapi yang tidak kalah penting lagi adalah pembangunan aspek politik perlu dibangun di perbatasan.

Aspek politik di perbatasan sudah sangat transparan dan demokratis di kembangkan. Situasi ini dapat terlihat partisipasi masyarakat yang terlibat dalam kegiatan politik, mulai dari pencalegan dan sampai pada ikut mencalonkan diri sebagai Bupati dan wakil Bupati Kabupaten Kapuas Hulu. Dengan berkembangnya aspek politik ini diharapkan masyarakat akan lebih terbuka dalam setiap hal. Dimana kondisi sekarang sangat berbeda dengan apa yang terjadi pada masa Orde Baru.

Pemerintah Kabupaten Kapuas Huku bersinergi dengan pemerintah Provinsi bersama-sama merumuskan kepentingan bangsa dan negara teruma kebutuhan masyarakat yang ada di perbatasan, berdasarkan kasil observasi yang peneliti lajukan di wilyah perbatas serta berdasarkan wawancara dengan beberapa sumber informasi, bahwa dengan dibangunnya perbatasan oleh pemerintah terutama dengan dibukanya PLB telah memberikan manfaat yang besar bagi masyarakat di perbatasan dan daerah sekitarnya, serta umumnya masyarakat kapuas hulu umumnya.

Banyak kemudahan yang diperoleh setelah PLB dibangun dan dibuka untuk umum. Beberapa masyarakat yang diwawancarai mengatakan dari sisi ekonomi mereka sangat terbantu atas pemenuhan kebutuhan dengan adanya pembangunan PLB. Alasannya menurut masyarakat setempat dengan adanya pembangunn PLB dan ditetapkannya perbatasa sebagai kawasan strategis Nasinoal memberikan kesempatan kepada masyarakat menjadi lebih kreativ dalam berbagai pekerjaan, serta arus orang dan Barang ke badau menjadi lebih lancar dan ramai.

Pembangunan perbatasan di Indonesia merupakan kebijakan yang sangat strategis, karena menyangkut aspek-aspek yang sangat luas seperti politik, ekonomi, sosial, dan budaya. Perbatasan adalah merupakan cermin bagi bangsa, karena pintu masuk ke Indonesia adalah daerah perbatasan. Pembangunan kawasan perbatasan tersebut telah dibicarakan di tingkat internasional seperti yang telah dilakukan pada tahun 1956 melalui perjanjian di Jenewa, bahwa setiap negara yang mempunyai hubungan langsung dengan negara lain dan ingin menjalin hubungan dengan negara lain tetap mengacu pada perjanjian yang telah disepakati tersebut. Berdasarkan kesepakatan tersebut pemerintah Indonesia dan pemerintah Malaysia telah bekerja sama dalam menangani kawasan perbatasan masingmasing.

Pemerintah Indonesia dan Malaysia sama-sama menyadari bahwa pentingnya kawasan perbatasan dikelola dan ditata dengan baik akan memberikan dampak yang positif pada masyarakat setempat. Hal tersebut dikarekan jarak kedua negara tetangga ini sangat dekat dan adanya ikatan keluarga suatu kultur budaya yang sama baik Indonesia maupun Malaysia.

Pembangunan kawasan perbatasan Badau yang merupakan integral wilayah negara Indonesia dari segi politik merupakan keharusan bagi pemerintah Indonesia. Rendahnya perhatian pemerintah pusat terhadap 
masyarakat di perbatasan dimasa lalu membuat hubungan antara masyarakat di perbatasan Badau dengan masyarakat perbatasan Malaysia (Lubuk Antu, Serian, dan desa-desa lainnya di Malaysia) menjadi semakin dekat. Kondisi seperti ini membuat mereka saling berhubungan dengan cara, masyarakat yang ada di Badau membawa barang dagangan dari Indonesia dan dibawa ke Malaysia. Semua itu bersifat illegal, karena perbatasan pada saat itu belum dikelola dengan baik. Kegiatan illegal seperti penyelundupan kayu, ikan, bahkan TKI illegal yang merajalela, kegiatan-kegiatan tersebut mengganggu hubungan kedua negara yang bertetangga ini.

Pembangunan kawasan perbatasan juga akan mengangkat harkat dan martabat bangsa Indonesia terutama masyarakat yang ada di perbatasan. Daerah yang miskin dan terbelakang, membuat prilaku masyarakat menjadi sulit terkendali dan mereka akan mudah terprovokasi dengan hal-hal yang sifatnya negatif, sehingga akan timbul keinginan-keinginan untuk memisahkan dirinya dari dari negara Republik Indonesia. Seperti contoh di perbatasan sering terdengan ada isu patok batas berubah dan lain sebagainya, walaupun hanya isu tetapi secara politis itu akan mengganggu hubungan bilateral kedua negara. Hubungan kedua negara yang telah terjalin sangat baik harus dijaga dari prilaku-prilaku dari sekelompok orang yang tidak bertanggung jawab yang akan merugikan orang banyak secara keseluruhan.

Melihat kondisi-kondisi yang ada di perbatasan seperti dihadapkan pada kemiskinan dan masih lemahnya hukum yang berlaku di Indonesia menyebabkan pentingnya pemerintah untuk menyusun struktur organisasi pemerintah daerah maupun desa agar lebih berfungsi sebagai sarana bagi pemerintah untuk melihat dan memperbaiki keadaan yang ada. Contohnya di fungsikan kembali Lembaga Ketahanan Masyarakat Desa (LKMD), organisasi kepemudaan seperti Karang Taruna, Lembaga Sosial Masyarakat (LSM) yang peduli pada pembangunan masyarakat di desa dengan demikian pemerintah tidak terlalu sulit dalam merealisasikan pembangunan di kawasan perbatasan dengan menyatukan persepsi diantara organisasi-organisasi tersebut.

Pembangunan kawasan perbatasan khususnya di Kecamatan Badau jukan akan membuka kesempatan kerja bagi masyarakat setempat. Kurangnya lahan pekerjaan membuat masyarakat yang ada di perbatasan menjadi miskin, dengan dibangunkan kawasan perbatasan dapat mengurangi kemiskinan yang ada di Badau. Pembangunan di Badau memerlukan penanganan yang serius dari pemerintah, penanganan kawasan perbatasan ini melibatkan banyak instansi pemerintah, pemilik modal (swasta) juga partisipasi masyarakat. Keuntungan dibukanya kawasan perbatasan membuka isolasi daerah perbatasan, sarana transportasi menjadi pilihan untuk dibangun karena jalan merupakan penghubung antar daerah dengan dibangunnya kawasan perbatasan membuat informasi akan dapat lebih banyak didapatkan oleh masyarakat.

Pembangunan perbatasan khusunya Badau merupakan keharusan bagi pemerintah, dilihat dari sisi ekonomi masyarakat yang ada di perbatasan taraf hidupnya sangat rendah. Pembangunan yang dilakukan oleh pemerintah hanya terpusat di kota dan di pesisirnya saja tetapi kebijakan pemerintah untuk melihat kembali kondisi perbatasan di Badau sejak tahun 2001 telah memberikan suatu harapan 
bagi masyarakat yang ada di Badau untuk peningkatan taraf hidup mereka. Masyarakat di perbatasan yang selama ini berada dalam kemiskinan karena kurangnya perhatian pemerintah kepada mereka, telah mulai merasakan suatu perubahan guna memperbaiki kehidupan mereka.

Untuk menghubungkan masyarakat yang ada di Badau pemerintah telah membangun sarana transportasi untuk mereka isolasi desadesa yang ada di Badau. Terbukanya isolasi kawasan perbatasan akan memperlancar hubungan masyarakat juga akan meningkatkan produktivitasnya yang ada di perbatasan. Kemiskinan di perbatasan akibat kurangnya lapangan kerja yang ada, masyarakat di Badau untuk mencukupi kebutuhan mereka seharihari melakukan pekerjaannya ke wilayah Malaysia dengan melakukan penjualan barang yang dibawa dari Indonesia biasanya untuk masyarakat di perbatasan Malaysia lebih menyukai produk-produk dari Indonesia karena harganya lebih murah dibandingkan harga barang Malaysia.

Bedasarkan hasil wawancara yang dilakukan dengan Camat Badau, bahwa dengan terbukanya PLB Nanga Badau secara kualitas, taraf hidup masyarakat sudah mulai membaik, hal ini disebabkan oleh arus mobilisasi orang dan barang semakin lancar. Selain itu juga sudah mulai banyaknya masyarakat luar yang datang berkunjung ke perbatasan merupakan hal yang positif terkait dengan pendapatan masyarakat setempat. Selanjutnya berdasarkan wawncara dengan tokoh masyarakat perbatasan yang juga merupakan anggota salah satu partai, dikatakan bahwa banyak potensi wisata yang ada diperbatasan apabila dpublikasi keluar. Dengan terbukanya PLB akan memberikan kemudahan orang asing masuk ke perbatasan untuk menikmati pesona alam di bumi Kapuas Hulu umumnya dan alam di perbatasan khususnya.

Kebijakan untuk pembangunan di Badau merupakan cara bagi pemerintah untuk meningkatkan ekonomi masyarakat di perbatasan. Implikasi dari pembangunan tersebut akan terbuka isolasi desa yang sudah terjadi sekian lama, membuka lapangan kerja bagi masyarakat. Berdasarkan wawancara dengan sekretaris camat Badau bahwa pembangunan yang dilakukan semuanya berorientasi dalam menngkatkan kesejahteraan masarakat di perbatasan terutama di Kecamatan Badau. Dilihat dari besarnya investasi yang di tanamkan investor di Badau lebih diarahkan ke Perkebunan. Dari sektor ini cukup banyak masyarakat ang mendapatkan dampak positif dari investasi tersebut.

Sebagian upaya pembangunan manusia dan kemanusiaan Indonesia seutuhnya itu, terutama pembinaan dan pengembangan manusia sebagai sumber daya, agaknya telah pula memberi hasil yang cenderung positif sesuai dengan apa yang diharapkan dalam rangka pembangunan di perbatasan yang bertujuan untuk meningkatkan perekonomian masyarakat dapat dikatakan sudah mulai dirasakan cukup baik oleh masyarakat. Pola pekerjaan yang sudsh bervariasi memberikan ruang dan kesempatan pada masyarakat untuk memilih pekerjaan yang sesuai dengan kemampuan dan mnat masyarakat setempat. Pembangunan dilaksanakan di perbatasan merupakan keharusan yang dilakukan pemerintah, sebab perbatasan masih memiliki sumberdaya alam yang masih dapat dikembangan kan guna meningkatkan kesejahteraan masyarakat.

Berdasarkan wawancara dengan tokoh masyarakat. Pentingnya pembangunan perbatasan Badau diharapkan dapat 
mengurangi keluar masuknya barang-barang dari luar yang dapat merusak sendi-sendi kehidupan masyarakat. Di Badau karena berdekatan dengan Negara Malaysia begitu mudahnya masuk barang-barang tersebut seperti minuman keras. Masyarakatnya yang mayoritas adalah suku Dayak di tambah tenaga kerja yang ada di Badau yang menyukai barang-barang tersebut menyebabkan pengedaran minuman keras di Badau lebih terbuka dan sangat mudah didapat. Akan tetapi juga dilanjutkan oleh informan bukan berarti mereka tidak membutuhkan barang-barang dari luar, masyarakat diperbatasan bahkan hampir seluruh kebutuhan sehari-harinya masih mengandalkan barang dari Lubuk Antu. Yang dimaksudkan informan disini adalah barang-barang yang dapat merusak generasi muda itu yang jangan sampai beredar di Badau dan sekitarnya. Karena menurut informan generasi muda akan hilang kreativitas dan lain sebagainya apabila barang-barang seperti itu beredar diperbatasan.

Pembangunan sosial budaya msayarakat juga perlu dilakukan. Masyarakat perbatasan dan wawasan dan yang lain sebagainya juga seharusnya sama dengan masyarakat lainnya. Pembangunan sektor pendidikan, ekonomi dilakukan didaerah lain juga seharusnya sama dengan apa yang dilakukan di perbatasan. Pembangunan aspek hukum di daerah lain juga seharusnya sama dengan masyarakat diperbatasan. Ketertinggalan masyarakat dan kurangnya perhatian pemerintah dari sisi hukum membuat pola kehidupan masyarakat cenderung sepertinya tidak terlalu mematuhi hukum.

Sebagai contoh Perjudian yang menyebabkan tenaga kerja yang ada di Badau sangat sulit untuk berhasil dalam pekerjaannya. Kegiatan illegal yang tidak bisa dicegah akibat dari pemenuhan kebutuhan masyarakat itu sendiri. Aparat kepolisian dan perangkat desa yang ada di Badau sehendaknya dapat mengantisipasi kondisi-kondisi sosial yang sangat memperhatikan hal tersebut. Jika kondisi sosial itu tidak diperhatikan dan sulit diubah pembangunan perbatasan yang direncanakan untuk meningkatkan kesejahteraan masyarakat di Badau akan menjadi sia-sia.

Pembangunan yang dilaksanakan tidak hanya bertujuan untuk meningkatkan ekonomi masyarakat tetapi segi sosial tidak boleh diabaikan. Pemerintah orde baru yang menanamkan pemerintahan yang menganut pada pertumbuhan, pemerataan dan stabilitas nasional, melupakan satu hal yang sangat penting yaitu sosial budaya. Kehidupan sosial masyarakat pun harus dibina moral, umumnya masyarakat merupakan kunci dari keberhasilan pembangunan yang akan dilaksanakan pembangunan yang pada mulanya adalah untuk pemerataan pembangunan dan kesejahteraan, karena tidak diimbangi dengan sikap moral masyarakat yang baik menjadi percuma dan usaha yang sia-sia belaka.

Perbaikan struktur masyarakat yang ada di Badau telah dilaksanakan penyuluhanpenyuluhan mengenai fungsi perbatasan juga diberikan oleh pemerintah semakin majunya peradaban dan semakin lajunya arus transformasi informasi dan budaya menyebabkan perubahan yang ada di Badau menjadi lebih cepat. Penyakit masyarakat lainnya yang ada di Badau adalah semakin berkembangnya praktek prostitusi yang dahulunya di Badau tidak ada pekerjaanpekerjaan seperti itu tetapi karena mudahnya masuk orang-orang Malaysia ke Indonesia terutama ke Badau menyebabkann pekerjaan 
tersebut merupakan pilihan bagi pendatang yang ada di perbatasan.

Dengan dibangunnya kawasan perbatasan dan pengelolaan melibatkan banyak pihak tingkat keberhasilannya akan dapat tercapi dengan optimal. Pembangunan perbatasan merupakan program jangka panjang yang akan membuat masyarakat di perbatasan menjadi lebih baik lagi dengan dibangunnya perbatasan yang merupakan pintu gerbangnya bangsa Indonesia, akan membuat menuju diri bangsa menjadi lebih terangkat dengan melihat perbatasan yang terkelola dengan baik saja orang akan dapat menilai bahwa bangsa Indonesia adalah bangsa yang maju dan bangsa yang beradab.

Perbaikan ekonomi masyarakat juga diimbangi dengan perbaikan mental masyarakat, pembangunan tidak hanya berfokus pada pertambahan ekonomi dan pemerataan, tetapi juga lebih melihat faktor manusianya. Pembangunan juga lebih melihat kebutuhankebutuhan dasar manusia.

\section{PEMBAHASAN}

Berdasarkan wawancara, observasi dan dokumentasi yang peneliti dapatkan dalam penelitian ini ada beberapa hal yang yang dapat kami rekomendasikan bagi pemerintah Kabupaten Kapuas Hulu dan pemerintah Kalimantan barat umumnya bahwa:

a. Pembangunan bukan hanya terkait dengan seberapa banyaknya fisik yan terbangun, akan tetapi juga kualitas perlu diperhatikan. Kualitas yang ami maksudkan disini adalah kualitas sumberdaya manusia perlu ditingkatkan di perbatasan hal ini berkaitan dengan harga diri bangsa dan negara, kualitas pendidikan dan penunjang sistem pendidikan perlu ditingkatkan, agar masyarakat di perbatasan merasa puas terhadapa sistem dan kebijakan pendidikan di Negara sendiri.

b. Kebijakan dan program yang di laksanakan di wilayah perbatasan memperhatikan kearifan lokal di perbatasan dan Kapuas Hulu khususnya. Ini dimaksudkan agar program yang dilaksanakan seperti pemberdayan masyarakat dapat di dukung dan diikutimoleh semua lapisan masyarakat. Sebab sumberdaya alam yang dimiliki masyarakat diperbatasan masih cukup menjanjikan ntuk dikembangkan untuk kesejahteraan masyarakat di perbatasan itu sendiri.

c. Penegakan hukum serta pendidikan politik bagi masyarakat perlu dikembangkan agar masyarakat diperbatasan menjadi tembok dalam menjaga wilayah mereka sendiri dan menjadikan masyarakat diperbatasan memiliki rasa cinta tanah air. Ini akan terwujud apabila kebutuhan masyarakat dapat dipenuhi oleh pemerintah.

\section{SIMPULAN}

Perbatasan merupakan wilayah yang sangat strategis untuk dikembangkan. Potret kehidupan masyarakat diperbatasan akan menggambarkan kehidupan masayarat suatu Negara. Begitu juga dengan Perbatasan Badau Kabupaten Kapuas Hulu. Masyarakat di perbatasan yang pada pemerintahan sejak Bangsa Indonesia merdeka jauh dari hiruk pikuk pembangunan. Pembangunan di perbatasan yang sudah mulai terasa dan dirasakan masyarakat di perbatasan sejak masa pemerintahan Susilo Bambang Yudhoyono. Dimana perbatasan sudah menjadi prioritas dengan berbagai program pembangunan Nasionalnya. 
Berdasarkan hasil penelitian yang dilakukan pembangunan di perbatasan Badau Kabupaten Kapuas Hulu masyarakat diperbatasan menyambut Positif pembangunan yang dilakukan oleh Pemerintah Pusat maupun Pemerinah daerah. Dimana sektor pendidikan, sektor ekonomi, sosial budaya dan Politik sudah cukup baik di perbatasan. Tanggapan positif ini merupakan modal bagi pemerintah untuk melanjutkan pembangunan yang didasarkan program untuk meningkatkan harkat dan martabat masyarakat di perbatasan.

Dengan terbangunnya pembangunan diperbatasan terutama dengan terbukanya PLB di Kecamatan badau telah memberikan kontribusi Positif terhadap pertumbuhan ekonomi masyarakat di Kecamatan Badau dan sekitarnya. Roda ekonomi bergerak dengan baik selama badau dibangun PLB. Selain itu juga pendidikan sudah cukup maju, dimana masyarakat sudah dapat menikmati pendidikan yang diberikan oleh negara sendiri dengan fasilitas yang sudah memadai, seperti tersedianya gedung sekolah yang layak serta tersedia guru yang mengajar. Selain itu juga masyarakat dalam aspek politik tidak sebagai obyek politik akan tetapi masyarakat sebagai subyek politik dan keikutsertaan masyarakat dalam membangun dan memberdayakan diri sendiri sudah sangat nyata di wilayah perbatasan.

\section{IMPLIKASI DAN KETERBATASAN}

Kabupaten Kapuas Hulu merupakan Kabupaten secara geografis sangat potensial untuk dikembangkan menjadi daerah yang maju, kemajuan daerah akan berimbas pada peningkatan kesejahteraan masyarakat. Kesejahteraan masyarakat di Kabupaten Kapuas Hulu di bandingkan dengan beberapa kabupaten yang ada di kalimatan barat tidaklah terlalu jauh perbedaannya. Agar kesejahteraan masyarakat dapat ditingkatkan campur tangan pemerinah sangat diperlukan. Campur tangan pemerintah dapat dilihat dari kebijakan yang dibuat pemerintah serta komitmen pemerintah dalam melaksanakan kebijakan yang dibuat.

Kebijakan pemerintah kabuaten kapuas hulu terkait dengan peningkatan kesejahteran dan menanggulangi kemiskinan di daerah ini perlu disenirgikan dengan kebijakan pemerintah Pusat. Pembangunan di daerah terpencil, terdepan, terluar dan perbatasan merupakan komitmen pemerintah pusat. Oleh sebab itu keterbatasan anggaran yang dimilii pemerintah daerah dapat di tanggulangi secara bersama-sama melalui APBD dan APBN. Selain itu dalam kontek pembuatan kebijakan dan program pembangunan yang akan dilaksanakan perlu mendapat masukan dari masyarakat, agar partisipasi masyarakat dalam berbagai kegiatan dapat terserap oleh pemerintah. Dewasa ini pembangunan yang partisipatif perlu di implementasikan. Tanpa partisipasi masyarakat mungkin kebijakan yang di buat pemerinttah sulit untuk mendapatkan hasil yang memuaskan dan berdampak terhadap kehidupan masyarakat. Luasnya wilayah yang ada di kapuas Hulu merupakan salah satu faktor yang di alami peneliti dalam melaksanakan penelitian ini. Akan tetapi secara umum apa ang dilakukan dalam pelaksanaan penelitian ini dapat tergambar dari hasil wawancara yang dilakukan kepada informan. Oleh karena itu peneliti memilih informan benar benar orangorang yang memahami keadaan dan permasalahan kapuas hulu secara baik. Informan ini selain sebagai aktor yang membuat kebijakan juga sebagai pelaksana dalam kebijakan yang telah dibuat. 


\section{REFERENSI}

Adisasmita, Rahardjo. (2006). Membangun Desa Partisipatif. Jakarta: Penerbit Graha Ilmu.

Amirin, Tatang M. (1990). Menyusun Rencana Penelitian. Jakarta: Rajawali Press.

Arikunto, Suharsimi. (1993). Prosedur Penelitian, Suatu Pendekatan Praktek, Jakarta: PT Rineka Cipta.

Dunn, William N. (2000). Pengantar Analisis Kebijakan Publik. Penterjemah Samudra Wibawa. Yogyakarta: Gajahmada University Press.

Islamy Irfan. M. (2000). Prinsip-Prinsip Perumusan Kebijaksanaan Negara. Jakarta: Bumi Aksara.

Kartasasmita, Ginanjar. (1996). Pembangunan Untuk Rakyat Memadukan Pertumbuhan dan Pemerataan. Jakarta: Cides.

Moleong, Lexy J. (1994). Metodologi Penelitian Kualitatif. Jakarta: PT Remaja Rosadakarya.

Nugroho, Riant. (2003). Kebijakan Publik Formulasi, Implementasi dan Evaluasi. Jakarta: PT.Elex Media Komputindo.

Singarimbun, Masri. (1989). Metode Penelitian Survey. Edisi Revisi. Jakarta: LP3ES Anggota IKAPI.

Suradinata, Ermaya. (1993). Kebijaksanaan Pembangunan dan Pengawasan Otonomi Daerah. Bandung: Penerbit Ramadhan.

Suharto, Edi. (2013). Kemiskinan dan Perlindungan Sosial di Indonesia (Menggagas Model Jaminan Sosial Universal Bidang Kesehatan). Bandung: Alfabeta.

Wahab, Solichin Abdul. (2016). Analisis Kebijaksanaan (dari Formulasi ke Implementasi Kebijaksanaan Negara). Jakarta: Bumi Aksara. 